\title{
Short rib-polydactyly syndrome
}

\author{
INSERM
}

\section{Source}

INSERM. (1999). Orphanet: an online rare disease and orphan drug data base. Short ribpolydactyly syndrome. ORPHA:1505

Short rib-polydactyly syndromes are a group of bone malformations characterized by a narrow thorax and polydactyly (usually preaxial). 